\title{
Field theory beyond the nation state
}

\author{
Julian Hamann \\ Humboldt University of Berlin
}

\begin{abstract}
At first glance, Bourdieu's field theory might be considered an unlikely case for research on transnational and global phenomena. However, scholarship in the last two decades shows that field analysis can indeed be useful to study cases beyond the national realm. Reviewing this research, this contribution is organized in three sections: It starts with a discussion of the (post-)national orientation of the field theoretical research program and outlines the ontology of transnational and global processes according to this program. Second, the contribution reviews the main strands of postnational field analysis and distills from this literature the empirical foci and analytical priorities. The third section takes stock of the theoretical efforts that have recently been made to de-nationalize the field theoretical research program and identifies the theoretical and conceptual contributions made in the process. The contribution concludes with an empirical, a methodological, and a theoretical question that should be addressed by future research.
\end{abstract}

\section{Keywords}

Bourdieu; Field theory; Autonomy; Relational; Education; Higher Education; Post-national; Transnational; International; Global 
These are proofs of the final publication available in the

Oxford Handbook on Education and Globalization, Oxford University Press

\section{How national is Bourdieusian field theory?}

Pierre Bourdieu developed his sociology mostly on domestic issues of European societies. He had a particular focus on the French society, and within France on education and higher education (Bourdieu and Passeron 1977, 1979, Bourdieu 1988, 1996b), but his research also attended to the French class society (Bourdieu 1984, 1999) and to literature and the arts (Bourdieu 1996a, 2017), to name just a few other examples. Although foundations of Bourdieu's theoretical work were laid by his early empirical studies of Kabyl life in Algeria (Bourdieu 1962, 1995) and he occasionally discussed processes of field internationalization (cf. Bourdieu 2005, 223-232), it is probably fair to say that large parts of his research - and, importantly, his theorizing - have been informed by phenomena within national orders. Fields, for Bourdieu, were primarily national fields.

Because the empirical point of reference for Bourdieu's research was usually national and often Francocentric, several 'nationalist' assumptions are engraved into his theory (cf. Schmitz and Witte 2020). For example, he conceptualizes societies as national societies (Bennett et al. 2009, 234-250). In addition, the two principles of social differentiation, classes and fields, are both situated within the national field of power and the national social space respectively (Vandenberghe 1999, Schmitz and Witte 2017). Not least, Bourdieu sees the mechanisms and institutions responsible for the legitimation and reproduction of social order as granted, organized, and controlled by the nation state (Bourdieu 2014). Despite such 'nationalist' assumptions in Bourdieu's own theorizing, a diagnosis of methodological or, indeed, epistemic nationalism would be misguided if it was aimed at the field theoretical research program per se. By principle, the research program of field theory goes beyond the work of Bourdieu himself (Wacquant 1992a). It does not exhaust itself in the mechanical application of the same theoretical concepts to ever new empirical phenomena. In the following I will join other scholars who have rejected the claim that field theory is impeded by epistemic nationalism and who have argued that such a claim neglects the very epistemological foundations of the field theoretical research program (cf. Go and Krause 2016b, Krause 2020, Schmitz and Witte 2020).

A core principle of the field theoretical research program is the relational co-constitution of theory, methodology, and epistemology (Bourdieu and Wacquant 1992). According to this principle, theory is always deeply engrained in methodological and epistemological considerations and vice-versa. Thus, theoretical concepts like 'field' do not come ready-made with definitions, waiting to be mechanically applied and filled with empirical content. Rather, field theoretical concepts convey a particular way of studying social phenomena. The scope of such phenomena is an empirical question. Indeed, any a priori commitment to 'the national' and 'the global' is overcome by field theory's relational approach to start not from entities, but to establish relevant research objects through relations between units of analysis (Bourdieu 1998, cf. Vandenberghe 1999). According to the relational approach, the local, 
regional, national, transnational, or global character of empirical phenomena is not determined by their very essence, but with reference to the phenomena's relations to other phenomena (cf. Krause 2020). Rather than starting from actors, the field theoretical research program invites us to start from relationships between actors and to investigate the common orientations or stakes that define the relationships between them. A field, then, is the structured realm that emerges from relations between actors. Because both the construction of relevant stakes and actors' relations may be located on and between different geo-spatial scales, the concept of 'field' is neither theoretically nor empirically committed to a specific scale.

What is more, the very claim to a specific geo-spatial scale is often enough part and parcel of actors' struggles and stakes. Higher education provides ample evidence for this: The national orientation of higher education systems has to be perceived as a historical specificity. For instance, in Germany, a field of higher education that is oriented towards the national scale emerged a mere 200 years ago. Before that, large parts of the German-speaking world were fragmented according to territorial principalities and ecclesiastical confessions. What was at stake for universities was the favor - both in symbolic and material terms - of princes and municipalities (cf. Rüegg 1996). The very notion that the geo-spatial realm towards which universities are oriented is actually a 'national state' was itself a matter of symbolic struggles. Those struggles were resolved with the proclamation of a German national state in 1871, a political project to which universities contributed the national narratives that were needed for imperial Germany (Ringer 1990, Gengnagel and Hamann 2014). Hence, if universities today compete for funding and status in national fields of higher education (Hicks 2012), their orientation towards the national scale has to be historicized as a result of symbolic struggles. Other actors contest this national orientation. For example, the European Union claims that the definition of good research and the distribution of resources can also be organized at the European level (König 2017, Baier and Gengnagel 2018). Ranking agencies and media corporations even go beyond the European scale and try to engage universities in a global competition for status and visibility (Wedlin 2010, Kauppi 2016, Brankovic, Ringel, and Werron 2018).

The example of higher education conveys, first, that the geo-spatial range of fields is a historical specificity and, second, that the very question which scales a field is oriented towards is often a contested issue in the field itself. The above example also illustrates a crucial third point: Different scales can matter at the same time (Krause 2017, Schmitz and Witte 2021). Not only can national higher education systems remain relevant if a relatively autonomous European field of higher education emerges. What is more, a strong national sphere can actually be a vital feature of a European field (cf. Schwarz and Westerheijden 2007). Fields can be oriented towards different geo-spatial scales at the 
same time, and different scales can be of varying significance for a field. Indeed, it is likely that a field's orientation towards one scale affects its orientation towards other scales (Sapiro 2018).

The field theoretical research program allows us to see that local, regional, national, transnational, and global orders are produced according to the same principles, that is, as a social space that is structured by relations between actors and defined by their common orientation towards specific stakes. Just as national fields emerge when stakes are constructed on the national scale (cf. Bourdieu 1994), processes of transnationalization are propelled by consecrating authorities that encourage actors to orient themselves towards stakes on the transnational level. More specifically, such processes of transnationalization imply, first, a (gradual) change of consecrating authorities and institutions, second, a change of the level on which actors orient their struggles, and third, a change in the constellation of agents involved (Sapiro 2018).

Such changes throughout processes of transnationalization are illustrated by current developments in fields of education. In many regards, fields of education remain deeply embedded on the national scale. Education has a reproductive function for the class structure of national societies, it is anchored in national education systems, institutions, and policies, career paths for teachers are national and, at least in some countries, education is funded by the state. Not least, education is indispensable for maintaining the symbolic power of the nation state, for example, because it issues certificates, and cultivates national languages and cultures (Bourdieu 2014). Yet, the national orientation of fields of education is currently challenged.

These challenges can be observed in education policy, where institutions and authorities of consecration on the national level now compete with other actors on regional, international, and transnational scales. What is at stake in these competitions is the definition of standards for good education, standards that are, for example, also claimed by the PISA tests of the OECD (cf. Lawn and Lingard 2002). Accrediting agencies and political authorities like the OECD and the European Union exert forces of transnationalization on fields of education (King 2007, Dugonjic-Rodwin 2021). Through the lens of field theory, such forces of transnationalization do not necessarily contradict the national orientation of educational fields: As I have argued above, fields can be oriented simultaneously towards the national, the transnational, and other scales. For example, PISA integrates fields of education on a transnational scale (Grek 2012), at the same time, PISA results are widely deployed to shape national education policies (Rautalin and Alasuutari 2009, Takayama 2010, Waldow, Takayama, and Sung 2014), and not least, PISA results are recontextualized on the local level according to specific constellations of actors and institutions (Hartong and Nikolai 2017). Thus, processes of localization, nationalization, and transnationalization play out at the same time. The examples illustrate that there 
is neither a zero-sum relationship between the national and the global nor are these processes necessarily unidirectional (cf. Sassen 2006).

The recent developments in higher education and education explain why research on these very fields has played an important role in pushing field theory beyond the nation state and dismissing the national as an a priori analytical category. Yet, the move beyond the national scale has not been limited to studies on higher education and education. It has been a major concern in field analysis in general. In the last 20 years, a vibrant literature has formed to investigate phenomena beyond the national scale (cf. Go and Krause 2016a, Schmidt-Wellenburg and Bernhard 2020a). This research perspective, for which I adopt the label "post-national analysis of fields" (introduced by Krause 2020), does not take the national for granted as a self-evident scale of social life and it does not ascribe to it any inherent ontological or epistemological qualities. For the literature concerned with the post-national analysis of fields, the national is not irrelevant per se, but the empirical focus is on contexts that go beyond the national scope. While the nation state played indeed a central role for Bourdieu's own research, the post-national take on the field theoretical research program assumes an agnostic stance towards the national. The following sections attend to this literature, focusing first on its empirical foci and analytical priorities, and then providing an overview over theoretical contributions to the post-national analysis of fields.

\section{The field of post-national field analysis: Empirical foci and analytical priorities}

Empirical contributions to the post-national analysis of fields cover a wide range of research objects. They attend to the transnational diffusion and reproduction of religious or humanitarian virtues and values (Krause 2014, Dromi 2016, Petzke 2016), to the transnational orientation of professions like journalism (Christin 2016, Hussain 2017) or law (Dezalay and Garth 1996, Vauchez 2008, Vauchez and de Witte 2013), or to supranational relations in societal spheres like economy (Lebaron 2010, Mudge and Vauchez 2016, Maeße 2018) and culture (Casanova 2004, Kuipers 2011, Buchholz 2016). Two empirical foci are of particular importance in post-national field analysis. First, contributions are often concerned with political entities, among them nation states and their transnational colonial pasts (Go 2008, Steinmetz 2008, Wilson 2016), relations between nation states (Adler-Nissen 2013, Schmitz, Heiberger, and Blasius 2015), or the emergence of political entities on the supranational scale (AdlerNissen 2011, Cohen 2011, Büttner and Mau 2014, Kauppi 2018). Second, perhaps the most prevalent empirical focus for post-national field analysis are fields of education and higher education. Contributions are concerned with transnational education policy instruments like PISA (Rawolle and Lingard 2008, Mangez and Hilgers 2012, Stray and Wood 2020) and highlight how transnational developments and fields affect educational fields on the national scale (Hartong 2020, Marttila 2020, 
cf. Dugonjic-Rodwin 2021). With view on higher education, scholars have noted how universities are oriented towards global struggles for reputation (Münch 2014), how global, transnational, and national orientations overlap in academic fields and disciplines (Heilbron, Guilhot, and Jeanpierre 2008, Heilbron 2014, Krause 2016), and how devices like rankings enforce fields to orient towards transnational stakes (Marginson 2008, Hamann and Schmidt-Wellenburg 2020).

Such an overview of empirical research objects across individual contributions provides valuable insights. It suggests that the empirical foci of post-national field analyses are similar to the foci of field analyses that are primarily concerned with fields on the national scale. In particular, the overview illustrates that political fields and fields of (higher) education are a core theme in both literatures. Yet, despite these insights it is more rewarding to distinguish contributions to post-national field analysis not according to empirical foci but regarding analytical priorities, that is, with view on the different attempts to transcend the national as the ex-ante geo-spatial unit of analysis. Although such distinctions are often gradual, they convey an analytical topology of the field of post-national field analysis. In the following, I will propose four levels of distinction.

One level of distinction concerns different approaches to geo-spatial scales. A large part of postnational field analyses focuses on the unilateral impact that transnational fields have on national fields, illustrating, for example, how national fields are structured by transnational influences (Hussain 2017), how national policy fields respond to transnational assessments (Stray and Wood 2020), how transnational fields intrude national fields (Petzke 2016), how transnational field effects realign fields and professions that have hitherto been oriented towards the national scale (Schmidt-Wellenburg 2017) and how national fields open up (Kuipers 2011) or even dissolve in the face of transnational influences (Mangez and Hilgers 2012). These studies are complemented by a second body of literature in which relations between transnational and national scales are conceptualized not as unilateral, but as bilateral. Scholars have noted, for example, how transnational and national fields affect each other and overlap (Krause 2016), how national fields draw from transnational fields and simultaneously affect their emergence (Dromi 2016), or how transnational fields have an impact on national fields, but the latter act back on the former (Stampnitzky 2016). A third strand of literature pursues a slightly different approach to geo-spatial scales. Here, contributions focus less on relations between different scales and more on relations between positions within transnational or global fields. This is the case in studies that examine how transnational or global fields structure relations between universities (Münch 2014), central bankers (Lebaron 2008), bureaucratic professionals (Büttner and Mau 2014), national literatures (Casanova 2004), nation states (Go 2008), countries as sites of cultural production (Buchholz 2018), or how positions and fractions in the fields of economics or the social sciences develop global orientations (Heilbron 2014, Maeße 2018). It is worth pointing out that at least two 
other possible approaches to geo-spatial scales are much less frequently pursued: Few studies are concerned with 'upward' unilateral relations according to which a national scale predominantly impacts a transnational sphere (but see Bigo 2007, Cohen 2011, Go 2020). Even less prevalent are postnational field analyses that abandon the national scale altogether and focus on relations between, for example, transnational and regional fields (but see Krause 2014).

In addition to different approaches to geo-spatial scales, a second level of distinction can contribute to an analytical topology of post-national field analysis. The field theoretical research program rests on the assumption that different field theoretical concepts relate to and build on each other (Wacquant 1992b). Just like a study of habitus has to be complemented by the concept of capital because habitus are structured by capital endowment, comprehensive analyses of fields can be expected to rely on a number of theoretical concepts that are not only neighboring but indeed analytically related to the concept of field. Yet, post-national field analyses seem to draw on a rather limited arsenal of theoretical concepts. ${ }^{1}$ The most prominent additional concept mobilized to construct transnational fields is capital, understood as common stakes that orient struggles in a specific field. Some contributions draw on established forms of capital, revealing, for example, how cultural and economic capital structure the transnational field of education policy (Mangez and Hilgers 2012), how transnational fields translate professional expertise into political capital (Schmidt-Wellenburg 2017), or how central bankers' positions in the global field of power are structured by political and economic capital (Lebaron 2008). Other studies identify new forms of capital, for example, ethnographic capital in the transnational field of colonial states (Steinmetz 2008), informational capital structuring the European field of security agencies (Bigo 2007), macro capital structuring the positions of countries, regions, or cities in a global field of cultural production (Buchholz 2018), literary capital in the global field of literature (Casanova 2004), and meta-capital structuring the relation among nation states in a global field of power (Schmitz, Heiberger, and Blasius 2015).

Another theoretical concept regularly mobilized to complement the concept of field in post-national analyses is the concept of autonomy, which describes the degree to which fields have a logic of their own and the capacity to organize field-specific practices (cf. Krause 2017). Contributions concerned with the relative autonomy and heteronomy of transnational or global fields examine, for example, the porous internal and external borders of the European legal field (Vauchez 2008), the heteronomizing effects of globalization on fields of national educational policy (Lingard, Rawolle, and Taylor 2005), how the relative autonomy of different national TV fields structures their incorporation into a transnational TV field (Kuipers 2011), and how researchers in the social sciences and humanities

1 This observation also holds true for field analyses primarily concerned with fields on the national scale. Thus, the kind of conceptual isolationism diagnosed here is no peculiarity of the post-national analysis of fields. 
mobilize the academic autonomy of their own field as a discursive strategy to gain advantages in the transnational field of European research funding (Baier and Gengnagel 2018). While the concepts of capital and, to a lesser degree, autonomy are regularly mobilized in post-national field analyses, only very few contributions go beyond this conceptual basic equipment. For example, Bourdieu's key concept of habitus rarely complements the concept of field (but see Adler-Nissen 2008, Vaara and Faÿ 2012, Büttner and Mau 2014, see also Carlson and Schneickert 2021 on the concept of habitus on transnational contexts). Other field theoretical concepts are even less prevalent. Illusio and doxa, describing the belief in field-specific values and orientations and the unquestioned acceptance of fieldspecific principles of order due to an alignment of mental and social structures, are mostly neglected or only mentioned in passing (but see Petzke 2016, Schmitz and Witte 2017).

Beyond different approaches to geo-spatial scales and the use of complementary field theoretical concepts, two additional levels of distinction can contribute to an analytical topology of the field of post-national field analysis: A third level of distinction concerns the methodological design of the respective studies. Many post-national field analyses are conceptualized as single case studies concentrating on one transnational or global field, for example, the transnational field of higher education (Marginson 2008, Münch 2014), the transnational field of European social law and social policy (Feritkh 2020), or the global field of power (Lebaron 2008, Schmitz, Heiberger, and Blasius 2015). Few contributions are conceptualized as multiple case studies with a focus on different fields and the relations between them. Exceptions are studies on how relations between transnational, national, and regional fields in the social sciences structure actors' positions and the prestige of research objects (Krause 2016), how gatekeepers regulate access to established positions in the academic field compared to the field of stand-up comedy (Hamann and Beljean 2021), or how different national TV fields are structured and relate to a transnational TV field (Kuipers 2011).

A fourth and last level of distinction that can convey a topology of post-national field analyses sheds light on the methods mobilized in the literature. A large share of contributions draws on qualitative, text-based methods, the majority being interview transcripts (Adler-Nissen 2008, Mudge and Vauchez 2016, Stray and Wood 2020), but also discourse analyses of documents (Baier and Gengnagel 2018, Maesse 2020), interpretative analyses of archived records (Dromi 2016, Wilson 2016) and memoirs (Stampnitzky 2016). Only few other qualitative methods are mobilized. For instance, ethnographic approaches are rather uncommon (but see Krause 2014). In comparison to qualitative methods, quantitative or quantifying methods are less prevalent in post-national field analyses. Exceptions are occasional applications of descriptive statistics (Marginson 2008, Münch 2014, Buchholz 2018) and methods of geometric data analysis (Lebaron 2008, Schmitz, Heiberger, and Blasius 2015, Baier and 
Gengnagel 2018, Dugonjic-Rodwin 2021). In sum, the methodological topology of post-national field analysis seems somewhat similar to analyses of primarily national fields.

This tentative topology suggests some lessons to learn for the study of education and higher education. The most obvious lesson is that the field theoretical research program is by no means limited to the national scale. The overview illustrates a rich diversity of empirical studies of transnational and global fields. Yet, the topology also highlights some issues and orientations that have thus far been neglected. Post-national field analyses of (higher) education could attend to these issues in the future. First, research should pay more attention to fields 'below' the national scale, a perspective that promises valuable insights particularly into systems in which (higher) education policy is also located at the state level. Research should also consider multilateral relations between fields oriented towards the local, the state, the national, and the transnational scale. Second, the overview conveys what I coin 'conceptual isolationism', according to which post-national field analyses rarely make use of field theory's full conceptual arsenal. Approaches that are more comprehensive in conceptual terms promise a more saturated and profound field theoretical account. To increase their theoretical saturation, post-national field analyses of (higher) education should therefore take into account concepts related to the concept of field. Third, the topology suggests some rather untrodden methodological paths to follow. Both multiple case studies, in which fields are compared or examined according to their relation to each other, and quantitative and quantifying methods are less prevalent and could be mobilized more often in post-national field analyses of (higher) education.

Post-national field analyses in general and analyses of fields of (higher) education in particular can not only draw from the existing literature reviewed in this section and attend to the issues that have been neglected thus far. Future research can also build on several theoretical and conceptual innovations that have been developed in post-national analyses of fields. Because the literature on post-national field analysis does not always explicitly leverage these innovations, the theoretical and conceptual contributions will be highlighted in the following section.

\section{Theoretical and conceptual innovations in the post-national analysis of fields}

Attempts to move field theory beyond the national scale have yielded a number of theoretical and conceptual innovations. These innovations proceed from two gradually different strategies of theorizing: One strategy is to rescale existing field theoretical concepts to make them suitable for postnational analyses. This strategy modifies said concepts but leaves their fundamental analytical architecture more or less unchanged. A second strategy of theorizing proceeds from the insight that field theoretical concepts have to be revised more fundamentally to study transnational and global 
phenomena. The distinction between the two strategies is gradual because some contributions rescale certain field theoretical concepts while revising other concepts more fundamentally. Both strategies share the insight that field theoretical concepts are not only generative for analyzing transnational relations and phenomena but indeed for transcending ex-ante oppositions between different geospatial scales (cf. Go and Krause 2016b, Schmitz and Witte 2020).

Contributions to post-national field theory that pursue the first strategy of theorizing rescale theoretical concepts to be adequate to study transnational or global phenomena but leave the fundamental analytical architecture of said concepts unchanged. Rescaled for transnational or global fields, field theoretical concepts facilitate insights, for example, into the emergence of fields in terms of a differentiation of a social space from existing spaces (Buchholz 2016, Wilson 2016), into struggles, competition, and power relations within transnational fields (Krause 2016, Petzke 2016), into internal struggle or external disruption as sources for change in transnational fields (Go 2008), and into the effects transnational fields exert on different geo-spatial scales (Mudge and Vauchez 2016, Stampnitzky 2016). It is telling to review these innovations in light of my previous diagnosis of the conceptual isolationism of post-national field analysis. While the overview in the previous section has revealed that empirical research rarely makes use of the full theoretical arsenal of field theory, the examples above illustrate successful attempts to rescale some more general conceptual approaches of field theory - for example, the focus on field effects, on the emergence of fields, or on struggles and power relations.

The strategy of rescaling has not only been applied to theoretical concepts, but also to methodological principles. Scholars have pointed out that the field theoretical research program provides researchers with "a style of research with a distinct epistemology and methodology." (Schmidt-Wellenburg and Bernhard 2020b, 2) For example, one methodological principle that has been fruitfully rescaled to be applicable to fields beyond the national scale is the principle to actively construct empirical phenomena as objects of investigation, instead of taking them for granted. With view on transnational or global phenomena, this requires asking whether and how transnational or global practices differ from national practices, and how such practices relate to one another (cf. Bigo 2020, Hartong 2020). Another methodological principle of field theory is to attend to the generative characteristics of social phenomena. Rescaled for phenomena beyond the national scale, a focus on the notion of time and processes of becoming facilitates questions on the historical development of transnational or global practices and categories (cf. Go 2020, Maesse 2020). In sum, the strategy of rescaling both methodological principles and theoretical concepts has demonstrated a remarkable potential for illuminating phenomena and processes at transnational and global scales. 
Gradually distinct from the first strategy of rescaling is a second strategy of theorizing that sees the need for more general conceptual revisions. Attempting to avoid a "deductive reification" (Buchholz 2016,31 ) of a one-sided perspective from the global north, this strategy aims to move beyond the national scale by introducing not gradual, but more or less fundamental innovations that significantly extend the field theoretical research program. In the following, I will review four such innovations that emerge from this strategy of revising.

A first significant extension introduces the scale across which fields extend as a hitherto neglected property of fields alongside which fields can be distinguished (Krause 2017). According to this analytical proposition, it is an empirical question whether fields are initially located on one scale and then expand ('below' or 'above' the initial scale) or whether they are located across different scales from the outset (see also Benson 2005, Schmitz and Witte 2020). As a case in point, the higher education field illustrates that fields can be historically located simultaneously on a transnational and on a subnational scale before being nationalized. Treating their scale as a variable property of fields has analytical benefits because it facilitates several systematic questions (cf. Krause 2017). These questions concern, first, relations between different fields on the same scale (e.g., relations between national fields of education and national political fields), second, relations between fields of the same kind and on the same scale in different contexts (e.g., relations between national fields of education in different countries), and third, relations between fields of the same kind on different scales (e.g., relations between fields of education on the local, national, and transnational scale). Although the overview in section two has conveyed that post-national field analyses attend to a variety of different relations on different geo-spatial scales, this approach allows for a more systematic take on such relations.

Treating the scale of fields as a variable property facilitates a second important innovation for the field theoretical research program. An examination of the scale of fields comprises a systematic distinction between intra-national, cross-national, and trans-national relations between fields. Such a distinction of field relations has considerable analytical leverage. Not least, it allows for a differentiation of the central field theoretical concept of autonomy: Questions about the relation between fields on the same geo-spatial scale (e.g., the field of education and the political field in the United Kingdom (UK), or the fields of education in the UK and Romania) attend to what has been coined "horizontal autonomy.' (Krause 2017) Questions about the relation between fields of the same kind on different scales (e.g., the fields of education in the UK and the European Union) focus on what has been described as 'vertical autonomy.' (Buchholz 2016) Distinguishing vertical and horizontal autonomy facilitates, first, a more differentiated view on the relative autonomy of fields. For example, the UK field of education may be less autonomous from the UK political field than some of its national counterparts are from the political fields in their contexts (horizontal autonomy), but it may be more 
autonomous from the European scale compared to other national fields of education (vertical autonomy) (cf. Grek 2009, Grek and Ozga 2010). Second, a differentiation of the concept of autonomy facilitates insights into transnational and global phenomena. For example, global fields can emerge not by constituting their independence from other global fields, but by becoming relatively autonomous from the logics of various national fields of the same kind (cf. Buchholz 2013).

A different approach to the autonomy of transnational or global fields introduces the notion of 'weak fields.' Compared to the concepts of vertical and horizontal autonomy, the notion of weak fields is less distinct from the original field theoretical concept of relative autonomy. It describes a type of transnational field that entails elements of both settled and emerging fields. Like settled fields, weak fields are characterized by densely institutionalized settings in which established professionals compete upon commonly valued stakes, and like emerging fields, weak fields are interwoven with neighboring fields and characterized by a low degree of internal differentiation (Vauchez 2011). The 'weakness' of transnational fields thus refers both to their interstitial position as they are merged into other fields that are constituted more firmly and to the blurriness of their internal boundaries (cf. Vauchez 2008). Although the overview in the previous section has conveyed that some post-national field analyses mobilize the concept of autonomy, differentiations of the concept allow for a more finegrained approach to relative autonomy. The full analytical potential of these theoretical innovations has yet to be tapped by empirical analyses.

A third innovation that emerges from the strategy of revising theoretical concepts can be seen in attempts to employ the analytical category of a global field of power which relates, for example, financial elites (Lebaron 2008, 2010), hegemonic empires of the past (Go 2008), or current nation states and cultures according to their similarities and differences (Schmitz, Heiberger, and Blasius 2015). A concept to relate fields to each other - that is, a field of fields -, and thus a key component of field theory, Bourdieu has used the field of power mostly as a theoretical reference in studies on individual fields, but not explicated it in a dedicated study.. What is more, he located the field of power exclusively on the national scale where it is framed by the nation state (cf. Bourdieu 1996b, see also Schmitz, Witte, and Gengnagel 2016). Attempts to revise this concept for post-national analyses unfold considerable analytical potential. A revised concept of a field of power is particularly important for an approach coined generalized field theory (Schmitz and Witte 2020). Instead of rescaling theoretical concepts, this approach attempts to release field theory from any ex ante assumptions on geo-spatial scales. Consequently, the key concept of the approach is a generalized field of power that discards not only epistemic nationalism, but any epistemology that takes geo-spatial scales for granted (e.g., internationalization, globalization, or cosmopolitanism). A field of power that has been revised accordingly suggests 'the global' as the widest possible empirical and most general analytical frame of 
reference for research on social phenomena (Schmitz and Witte 2020, Schneickert, Schmitz, and Witte 2020, Schmitz and Witte 2021). Although some studies have put the concept of a global field of power to empirical use, the previous section has shown that most empirical contributions focus on transnational fields that span only selected parts of the world (i.e., the global north).

Postcolonial strands in the field theoretical research program also pursue the strategy of revising field theoretical concepts. From their efforts emerges a fourth substantial attempt to release the field theoretical research program from the specific geo-spatial context it has been developed in. Generally, postcolonial approaches challenge us to rethink hegemonic Western knowledges and to reconsider an epistemic unconscious from an alternative standpoint (Go 2017). Although Bourdieu himself did offer a theory of colonialism and a systematic understanding of its effects and logics (Go 2013), the field theoretical research program reveals imprints of hegemonic Western epistemology. Such imprints are illustrated, for example, by a distinct analytical focus on transnational constellations in the global north. Another example of the imprints of Western epistemology is field theory's taken for granted distinction between differentiated and non-differentiated societies. This distinction, symbolized by Bourdieu's work on the pre-capitalist, agrarian society of Kabylia on the one hand and by his work on the strongly differentiated French society on the other hand, organizes a number of oppositions between Western and non-Western, heterogeneous and homogeneous, complex and simple, modern and archaic (Hilgers and Mangez 2014). Postcolonial approaches attempt not only to replace the distinction between differentiated and non-differentiated societies with a continuum of more or less differentiated societies. They also show that the type of differentiation that field theory is concerned with is, in fact, a particular form of functional differentiation that has been developed from Western societies. Postcolonial approaches thus draw attention to alternative types of differentiation that concern language, ethnicity, or territory (cf. Steinmetz 2016). In sum, postcolonial perspectives are a powerful tool for reflexive post-national field analyses and a critique of the illusions of scholastic and epistemic universalism.

\section{Conclusion: Some open questions for the post-national analysis of fields}

Bourdieu's own research was mostly focused on fields oriented within the national scale. Yet, the field theoretical research program per se does not suffer from epistemological nationalism. Indeed, any a priori commitment to specific geo-spatial scales is overcome by field theory's relational approach to start not from entities, but to establish relevant research objects through relations between units of analysis. According to this methodological core principle, empirical phenomena are not local, regional, national, transnational, or global in essence. Rather, their geo-spatial range is to be determined empirically with reference to the phenomena's relations to other phenomena. Taking this principle 
seriously, the post-national analysis of fields has developed into a vast body of literature over the last two decades. It attends to various empirical foci, has pursued a number of analytical priorities, and brought about important theoretical and conceptual innovations. Research on education and higher education has played an important role in pushing field theory beyond the nation state because recent developments in (higher) education have made it necessary to dismiss the national as an a priori analytical category.

My contribution has demonstrated that the post-national analysis of fields has realized remarkable analytical leverage. Yet, a few open questions remain. I will conclude with an empirical, a methodological, and a theoretical question that should be addressed by future research.

An empirical question that remains to be answered by post-national analyses of fields concerns the functional equivalents of the state on the transnational or global scale (cf. Schmitz and Witte 2020). On the national scale, the state has a central role in the (re-)production of the material and symbolic order of societies. The "grip of the state" (Bourdieu 1994, 2) lies in its ability to impose universal symbolic forms and principles of vision and division. The state's ability to impose principles of social order ranges from the structure of time (i.e., the school calendar, secular and religious holidays, etc.) over the distinction between public and private space to the definition of social problems (Bourdieu 2014). Not least, there is a close complicity between the state and educational institutions in the (reIproduction of social order (Bourdieu 1996b). In its attempts to abandon 'the national', the postnational analysis of fields has successfully moved beyond the nation state as an a priori geo-spatial scale. Yet, the focus on geo-spatial entities has not corresponded with similar attention to the second meaning of the state as a site of material and symbolic power. Future research should therefore systematically inquire functional equivalents to state power on transnational or global scales. It should also examine the extent to which these functional equivalents can impose symbolic visions and divisions that might be as universal as those imposed by the nation state. With its focus on the symbolic power of entities like the European Union, the OECD, or media corporations like Bertelsmann or Times Higher Education, the study of transnational educational and political fields has thus far delivered the most promising insights in this regard.

A methodological question for post-national analyses of fields are geo-spatial scales 'below' the national. Recapitulating the literature reviewed in this contribution, it is obvious that most attempts of post-national field analysis either go 'above' or 'across' the national scale. In other words, postnational field analysis thus far focuses either on transnational or on global fields. Less attention has been paid to local or regional fields, and existing work on the matter has not been incorporated into the body of literature. This bias is remarkable if we call to mind that, according to the relational principle, empirical phenomena do not have a geo-spatial essence. Assuming that the current 
scholarship takes this principle seriously, there can only be two reasons for the prevalence of transnational and global fields in the existing literature: Either fields 'above' the national have a greater appeal to scholars, if only because transnational and global objects of research promise greater dividends in the academic field (Bourdieu 1969). Or fields are indeed geo-spatially extensive rather than contractive, that is, they tend to extend to spaces equal to or 'above' the national scale but less commonly contract 'below' the national. Such fundamental issues of the spatial expansion and contraction of fields should be addressed more systematically by post-national field analysis. More systematic research on local and regional fields would be a first step towards addressing this question.

A theoretical question future research should attend to concerns the geo-spatial scope of class (cf. Bennett et al. 2009). Bourdieu's theory is one of the few modern sociological theories that integrates two principles of social differentiation: the structure of fields and the structure of classes. Crucially, both principles are linked on a theoretical level through the concept of structural homology, which designates the parallels between the oppositions within fields and the oppositions in social space (i.e., the structure of class society). The degree to which these parallels manifest is an empirical question and concerns the relative autonomy of the field in question. Bourdieu's studies of the French fields of (higher) education give examples for a rather pronounced structural homology between the structures of social space and specific fields: In the academic field, differences separating the academic faculties are structurally homologous to the economic and social differences that form the opposition between the subordinate and dominant classes in French society (Bourdieu 1988, 41). The field of the Grandes Ecoles is structured to contribute to the reproduction of French class society (Bourdieu 1996b, 285). A post-national analysis of fields that concentrates only on fields runs danger of dissolving the theoretical link between fields and social space as two related principles of social differentiation. What is at stake here is not only theoretical comprehensiveness. An empirical approach to possible homologies between transnational or global fields and the - national or transnational - social space is also much better equipped to understand the positions and oppositions within the fields in question. Future research should therefore attempt to avoid the de-coupling of field and social space.

\section{References}

Adler-Nissen, Rebecca. 2008. "The Diplomacy of Opting Out: A Bourdieudian Approach to National Integration Strategies." Journal of Common Market Studies 46 (3):663-684.

Adler-Nissen, Rebecca. 2011. "On a Field Trip with Bourdieu." International Political Sociology 5 (3):327-330.

Adler-Nissen, Rebecca, ed. 2013. Bourdieu in International Relations: Rethinking Key-Concepts in IR. New York: Routledge. 
Baier, Christian, and Vincent Gengnagel. 2018. "Academic Autonomy Beyond the Nation-State. The Social Sciences and Humanities in the European Research Council." Österreichische Zeitschrift für Soziologie 43 (1):65-92.

Bennett, Tony, Mike Savage, Elizabeth Silva, Alan Warde, Modesto Gayo-Cal, and David Wright. 2009. Culture, Class, Distinction. London, New York: Routledge.

Benson, Rodney. 2005. "Mapping Field Variation: Journalism in France and the United States." In Bourdieu and the Journalistic Field, edited by Rodney Benson and Erik Neveu, 85-112. Cambridge: Polity Press.

Bigo, Didier, ed. 2007. The Field of the EU Internal Security Agencies. Paris: Centre d'études sur les conflits/l'Harmattan.

Bigo, Didier. 2020. "Adjusting a Bourdieusian approach to the study of transnational fields: Transversal practices and state (trans)formations related to intelligence and surveillance." In Charting Transnational Fields. Methodology fo a Political Sociology of Knowledge, edited by Christian Schmidt-Wellenburg and Stefan Bernhard, 55-78. London, New York: Routledge.

Bourdieu, Pierre. 1962. The Algerians. Boston: Beacon Press.

Bourdieu, Pierre. 1969. "Intellectual field and creative project." Social Science Information 8 (2):89119.

Bourdieu, Pierre. 1984. Distinction. A Social Critique of the Judgement of Taste. Cambridge: Cambridge University Press.

Bourdieu, Pierre. 1988. Homo Academicus. Cambridge: Polity Press.

Bourdieu, Pierre. 1994. "Rethinking the State: Genesis and Structure of the Bureaucratic Field." Sociological Theory 12 (1):1-18.

Bourdieu, Pierre. 1995. Outline of a theory of practice. Cambridge: Cambridge University Press.

Bourdieu, Pierre. 1996a. The Rules of Art. Genesis and Structure of the Literary Field. Stanford, California: Stanford University Press.

Bourdieu, Pierre. 1996b. The State Nobility. Elite Schools in the Field of Power. Cambridge: Polity Press.

Bourdieu, Pierre. 1998. Practical Reason. On the Theory of Action. Stanford: Stanford University Press.

Bourdieu, Pierre. 1999. The Weight of the World. Social Suffering in Contemporary Society. Stanford, California: Stanford University Press.

Bourdieu, Pierre. 2005. The Social Structures of the Economy. Cambridge: Polity Press.

Bourdieu, Pierre. 2014. On the State. Lectures at the Collège de France, 1989-1992. Cambridge: Polity Press.

Bourdieu, Pierre. 2017. Manet: A Symbolic Revolution. Cambridge: Polity Press.

Bourdieu, Pierre, and Jean-Claude Passeron. 1977. Reproduction in Education, Society, and Culture. London: Sage.

Bourdieu, Pierre, and Jean-Claude Passeron. 1979. The Inheritors. French Students and their Relation to Culture. Chicago, London: University of Chicago Press.

Bourdieu, Pierre, and Loïc D. Wacquant. 1992. An Invitation to Reflexive Sociology. Cambridge: Polity Press.

Brankovic, Jelena, Leopold Ringel, and Tobias Werron. 2018. "How Rankings Produce Competition: The Case of Global University Rankings." Zeitschrift für Soziologie 47 (4):270-288.

Buchholz, Larissa. 2013. The Global Rules of Art. PhD Dissertation. New York: Columbia University.

Buchholz, Larissa. 2016. "What is a global field? Theorizing fields beyond the nation-state." The Sociological Review 64 (2):31-60.

Buchholz, Larissa. 2018. "Rethinking the center-periphery model: Dimensions and temporalities of macro-structure in a global field of cultural production." Poetics 71 (2018):18-32.

Büttner, Sebastian, and Steffen Mau. 2014. "EU-Professionalismus als transnationales Feld." Berliner Journal für Soziologie 24 (2):141-167.

Carlson, Sören, and Christian Schneickert. 2021. "Habitus in the context of transnationalization: From 'transnational habitus' to a configuration of dispositions and fields." The Sociological Review, online first.

Casanova, Pascale. 2004. The World Republic of Letters. Cambridge: Harvard University Press. 
Christin, Angèle. 2016. "Is journalism a transnational field? Asymmetrical relations and symbolic domination in online news." The Sociological Review 64 (2):212-234.

Cohen, Antonin. 2011. "Bourdieu Hits Brussels: The Genesis and Structure of the European Field of Power." International Political Sociology 5 (3):335-339.

Dezalay, Yves, and Bryant G. Garth. 1996. Dealing in Virtue: International Commercial Arbitration and the Construction of a Transnational Legal Order. Chicago: Chicago University Press.

Dromi, Shai M. 2016. "For good and country: nationalism and the diffusion of humanitarianism in the late nineteenth century." The Sociological Review 64 (2):79-97.

Dugonjic-Rodwin, Leonora. 2021. "Field theory and education: a case study of the international baccalaureate." International Studies in Sociology of Education 30 (3):325-348.

Feritkh, Farim. 2020. "A weak field of social policy? A transnational perspective on the EEC's social policymaking (from the 1940s to the 1970s)." In Charting Transnational Fields. Methodology for a Political Sociology of Knowledge, edited by Christian Schmidt-Wellenburg and Stefan Bernhard, 178-195. London: Routledge.

Gengnagel, Vincent, and Julian Hamann. 2014. "The Making and Persisting of Modern German Humanities. Balancing Acts between Autonomy and Social Relevance." In The Making of the Humanities III. The Modern Humanities, edited by Rens Bod, Jaap Maat and Thijs Weststeijn, 641-654. Amsterdam: Amsterdam University Press.

Go, Julian. 2008. "Global Fields and Imperial Forms: Field Theory and the British and American Empires." Sociological Theory 26 (3):201-229.

Go, Julian. 2013. "Decolonizing Bourdieu: Colonial and Postcolonial Theory in Pierre Bourdieu's Early Work." Sociological Theory 31 (1):49-74.

Go, Julian. 2017. "Decolonizing Sociology: Epistemic Inequality and Sociological Thought." Social Problems 64 (2):194-199.

Go, Julian. 2020. "Global change: A field theory perspective on the end of empire." In Charting Transnational Fields. Methodology for a Political Sociology of Knowledge, edited by Christian Schmidt-Wellenburg and Stefan Bernhard, 141-159. London, New York: Routledge.

Go, Julian, and Monika Krause, eds. 2016a. Fielding Transnationalism. Malden: Wiley Blackwell.

Go, Julian, and Monika Krause. 2016b. "Fielding Transnationalism: An Introduction." The Sociological Review 64 (2):6-30.

Grek, Sotiria. 2009. "Governing by numbers: the PISA 'effect' in Europe." Journal of Education Policy $24(1): 23-37$.

Grek, Sotiria. 2012. "What PISA Knows and Can Do: Studying the Role of National Actors in the Making of PISA." European Educational Research Journal 11 (2):243-254.

Grek, Sotiria, and Jenny Ozga. 2010. "Governing education through data: Scotland, England and the European education policy space." British Educational Research Journal 36 (6):937-952.

Hamann, Julian, and Stefan Beljean. 2021. "Career Gatekeeping in Cultural Fields." American Journal of Cultural Sociology 9 (1):43-69.

Hamann, Julian, and Christian Schmidt-Wellenburg. 2020. "The Double Function of Rankings. Consecration and Dispositif in Transnational Academic Fields." In Charting Transnational Fields. Methodology for a Political Sociology of Knowledge, edited by Stefan Bernhard and Christian Schmidt-Wellenburg, 160-177. London: Routledge.

Hartong, Sigrid. 2020. "Tracing 'the transnational' in the nationalization of school policy: The transformation of standards-based reform in the United States." In Charting Transnational Fields. Methodology for a Political Sociology of Knowledge, edited by Christian SchmidtWellenburg and Stefan Bernhard, 240-256. London, New York: Routledge.

Hartong, Sigrid, and Rita Nikolai. 2017. "Observing the 'Local Globalness' of Policy Transfer in Education." Comparative Education Review 61 (3):519-537.

Heilbron, Johan. 2014. "The social sciences as an emerging global field." Current Sociology 62 (5):685703.

Heilbron, Johan, Nicolas Guilhot, and Laurent Jeanpierre. 2008. "Toward a Transnational History of the Social Sciences." Journal of the History of the Behavioral Sciences 44 (2):146-160. 
Hicks, Diana. 2012. "Performance-based university research funding systems." Research Policy 41 (2):251-261.

Hilgers, Mathieu, and Eric Mangez. 2014. "Theory of fields in the postcolonial age." In Bourdieu's Theory of Social Fields. Concepts and Applications, edited by Mathieu Hilgers and Eric Mangez, 257-273. London: Routledge.

Hussain, Naimah. 2017. "Bourdieu in Greenland: Elaborating the Field Dependencies of Post-colonial Journalism." In Present Scenarios of Media Production and Engagement, edited by Simone Tosoni, Nico Carpentier, Maria Francesca Murru, Richard Kilborn, Leif Kramp, Risto Kunelius, Anthony McNicholas, Tobias Olsson and Pille Pruulmann-Vengerfeldt, 123-135. Bremen: edition Lumière.

Kauppi, Niilo. 2016. "Ranking and the Structuration of a Transnational Field of Higher Education." In A European Politics of Education: Perspectives from Sociology, Policy Studies and Politics, edited by Romuald Normand and Jean-Louis Derouet, 92-103. Abingdon: Routledge.

Kauppi, Niilo. 2018. Toward a Reflexive Political Sociology of the European Union. Fields, Intellectuals and Politicians. Cham: Palgrave Macmillan.

King, Kenneth. 2007. "Multilateral Agencies in the Construction of the Global Agenda on Education." Comparative Education 43 (3):377-391.

König, Thomas. 2017. The European Research Council. Cambridge: Polity Press.

Krause, Monika. 2014. The Good Project: Humanitarian NGOs and the Fragmentation of Reason. Chicago: University of Chicago Press.

Krause, Monika. 2016. "'Western hegemony' in the social sciences: fields and model systems." The Sociological Review 64 (2):194-211.

Krause, Monika. 2017. "How fields vary." British Journal of Sociology 69 (1):3-22.

Krause, Monika. 2020. "The post-national analysis of fields." In Charting Transnational Fields. Methodology for a Political Sociology of Knowledge, edited by Christian Schmidt-Wellenburg and Stefan Bernhard, 98-112. New York: Routledge.

Kuipers, Giselinde. 2011. "Cultural Globalization as the Emergence of a Transnational Cultural Field: Transnational Television and National Media Landscapes in Four European Countries." American Behavioral Scientist 55 (5):541-557.

Lawn, Martin, and Bob Lingard. 2002. "Constructing a European Policy Space in Educational Governance: The Role of Transnational Policy Actors." European Educational Research Journal 1 (2):290-307.

Lebaron, Frédéric. 2008. "Central Bankers in the Contemporary Global Field of Power: A 'Social Space' Approach." The Sociological Review 56 (1):121-144.

Lebaron, Frédéric. 2010. "European Central Bank Leaders in the Global Space of Central Bankers: A Geometric Data Analysis Approach." French Politics 8 (3):294-320.

Lingard, Bob, Shaun Rawolle, and Sandra Taylor. 2005. "Globalizing policy sociology in education: working with Bourdieu." Journal of Education Policy 20 (6):759-777.

Maeße, Jens. 2018. "Globalization strategies and the economics dispositive. Insights from Germany and the UK." Historical Social Research 43 (3):120-146.

Maesse, Jens. 2020. "The Euro crisis dispositif: Heterogeneous positioning strategies in polycentric fields." In Charting Transnational Fields. Methodology for a Political Sociology of Knowledge, edited by Christian Schmidt-Wellenburg and Stefan Bernhard, 219-239. London, New York: Routledge.

Mangez, Eric, and Mathieu Hilgers. 2012. "The Field of Knowledge and the Policy Field in Education: PISA and the production of knowledge for policy." European Educational Research Journal 11 (2):189-205.

Marginson, Simon. 2008. "Global field and global imagining: Bourdieu and worldwide higher education." British Journal of Sociology of Education 29 (3):303-315.

Marttila, Tomas. 2020. "The rise of a European field of evidence-based education." In Charting Transnational Fields. Methodology of a Political Sociology of Knowledge, edited by Christian Schmidt-Wellenburg and Stefan Bernhard, 196-218. London: Routledge. 
Mudge, Stephanie L., and Antoine Vauchez. 2016. "Fielding supranationalism: the European Central Bank as a field effect." The Sociological Review 64 (2):146-169.

Münch, Richard. 2014. Academic Capitalism. Universities in the Global Struggle for Excellence. New York: Routledge.

Petzke, Martin. 2016. "Taken in by the numbers game: the globalization of a religious 'illusio' and 'doxa' in nineteenth-century evangelical missions to India." The Sociological Review 64 (2):124-145.

Rautalin, Marjaana, and Pertti Alasuutari. 2009. "The uses of the national PISA results by Finnish officials in central government." Journal of Education Policy 24 (5):539-556.

Rawolle, Shaun, and Bob Lingard. 2008. "The sociology of Pierre Bourdieu and researching education policy." Journal of Education Policy 23 (6):729-741.

Ringer, Fritz K. 1990. The decline of the German mandarins: the German academic community, 18901933. Lebanon, New England: University Press of New England.

Rüegg, Walter. 1996. A History of the University in Europe, Vol. II Universities in Early Modern Europe (1500-1800). Cambridge: Cambridge University Press.

Sapiro, Gisèle. 2018. "Field Theory from a Transnational Perspective." In The Oxford Handbook of Pierre Bourdieu, edited by Thomas Medvetz and Jeffrey J. Sallaz, online. Oxford: Oxford University Press.

Sassen, Saskia. 2006. Territory, Authority, Rights: From Medieval to Global Assemblages. Princeton: Princeton University Press.

Schmidt-Wellenburg, Christian. 2017. "Europeanisation, stateness, and professions: what role do economic expertise and economic experts play in European political integration?" European Journal of Cultural and Political Sociology 4 (4):430-456.

Schmidt-Wellenburg, Christian, and Stefan Bernhard, eds. 2020a. Charting Transnational Fields. Methodology for a Political Sociology of Knowledge. London, New York: Routledge.

Schmidt-Wellenburg, Christian, and Stefan Bernhard. 2020b. "How to chart transnational fields. Introduction to a methodology for a political sociology of knowledge." In Charting Transnational Fields. Methodology for a Political Sociology of Knowledge, edited by Christian Schmidt-Wellenburg and Stefan Bernhard, 1-33. London, New York: Routledge.

Schmitz, Andreas, Raphael H. Heiberger, and Jörg Blasius. 2015. "Das globale Feld der Macht als 'Tertium Comparationis'." Österreichische Zeitschrift für Soziologie 40 (3):247-263.

Schmitz, Andreas, and Andreas Witte. 2021. "Relational Sociology on a Global Scale: Perspectives from Field Theory on Cross-Cultural Comparison, and the Re-Figuration of Space(s)." Forum Qualitative Sozialforschung, Themed Issue 'The Re-Configuration of Spaces and Cross-Cultural Comparison'.

Schmitz, Andreas, and Daniel Witte. 2017. "Der Nationalstaat und das globale Feld der Macht, oder: Wie sich die Feldtheorie von ihrem methodologischen Nationalismus befreien lässt." Zeitschrift für theoretische Soziologie 6 (2):156-188.

Schmitz, Andreas, and Daniel Witte. 2020. "National, international, transnational, and global fields. Theoretical clarifications and methodological implications." In Charting Transnational Fields. Methodology for a Political Sociology of Knowledge, edited by Christian Schmidt-Wellenburg and Stefan Bernhard, 79-97. London, New York: Routledge.

Schmitz, Andreas, Daniel Witte, and Vincent Gengnagel. 2016. "Pluralizing field analysis: Toward a relational understanding of the field of power." Social Science Information/Information sur les sciences sociales 56 (1):49-73.

Schneickert, Christian, Andreas Schmitz, and Daniel Witte. 2020. Das Feld der Macht. Eliten Differenzierung - Globalisierung. Wiesbaden: VS Verlag.

Schwarz, Stefanie, and Don F. Westerheijden, eds. 2007. Accreditation and Evaluation in the European Higher Education Area. Dordrecht: Springer.

Stampnitzky, Lisa. 2016. "The lawyers' war: states and human rights in a transnational field." The Sociological Review 64 (2):170-193.

Steinmetz, George. 2008. "The Colonial State as a Social Field: Ethnographic Capital and Native Policy in the German Overseas Empire before 1914." American Sociological Review 73 (2):589-612. 
Steinmetz, George. 2016. "Social fields, subfields and social spaces at the scale of empires: explaining the colonial state and colonial sociology." The Sociological Review 64 (2):98-123.

Stray, Janicke Heldal, and Bronwyn Wood. 2020. "Global-local Education Policy Dynamics: A Case Study of New Zealand and Norway." Scandinavian Journal of Educational Research 64 (2):256-269.

Takayama, Keita. 2010. "Politics of Externalization in Reflexive Times: Reinventing Japanese Education Reform Discourses through 'Finnish PISA Success'." Comparative Education Review 54 (1):5175.

Vaara, Eero, and Eric Faÿ. 2012. "Reproduction and Change on the Global Scale: A Bourdieusian Perspective on Management Education." Journal of Management Studies 49 (6):1023-1051.

Vandenberghe, Fredereric. 1999. "'The Real is Relational': An Epistemological Analysis of Pierre Bourdieu's Generative Structuralism." Sociological Theory 17 (1):32-67.

Vauchez, Antoine. 2008. "The Force of a Weak Field: Law and Lawyers in the Government of the European Union." International Political Sociology 2 (2):128-144.

Vauchez, Antoine. 2011. "Interstitial Power in Fields of Limited Statehood: Introducing a 'Weak Field' Approach to the Study of Transnational Settings." International Political Sociology 5 (3):340345.

Vauchez, Antoine, and Bruno de Witte, eds. 2013. Lawyering Europe. European Law as a Transnational Social Field Oxford: Hart.

Wacquant, Loïc D. 1992a. "Preface." In An Invitation to Reflexive Sociology, edited by Pierre Bourdieu and Loïc D. Wacquant, ix-xiv. Cambridge: Polity Press.

Wacquant, Loïc D. 1992b. "Toward a Social Praxeology: The Structure and Logic of Bourdieu's Sociology." In An Invitation to Reflexive Sociology, edited by Pierre Bourdieu and Loïc D. Wacquant, 1-59. Cambridge: Polity Press.

Waldow, Florian, Keita Takayama, and Youl-Kwan Sung. 2014. "Rethinking the pattern of external policy referencing: media discourses over the 'Asian Tigers" PISA success in Australia, Germany and South Korea." Comparative Education 50 (3):302-321.

Wedlin, Linda. 2010. "Going Global. Rankings as Rhetorical Devices to Construct an International Field of Management Education." Organization 42 (2):199-218.

Wilson, Nicholas Hoover. 2016. "Moral accounting as field foundation in an early modern empire: the English East India Company in the late eighteenth century." The Sociological Review 64 (2):6178. 